\title{
UJI DAYA HAMBAT SENYAWA SAPONIN BATANG PISANG (Musa paradisiaca) TERHADAP PERTUMBUHAN Candida albicans
}

\author{
${ }^{1}$ Siti R. I. Yuliana \\ ${ }^{2}$ Michael A. Leman \\ ${ }^{2}$ P. S. Anindita \\ ${ }^{1}$ Kandidat Skripsi Program Studi Pendidikan Dokter Gigi Fakultas Kedokteran \\ ${ }^{2}$ Program Studi Pendidikan Dokter Gigi Fakultas Kedokteran \\ Universitas Sam Ratulangi Manado \\ Email: Lyaarahmatia@yahoo.com
}

\begin{abstract}
Candida albicans living as saprophyte can be found on the skin, genital tract, upper respiratory tract, and gastrointestinal tract including the oral cavity. The transmutation of Candida albicans from saprofit becoming pathogenic causes thrush or candidiasis. The treatment of oral candidiasis is antifungal drugs, however, long-term used of the drugs can make Candida albicans being resistant. Therefore, an alternative medicine with lower side effects is needed. One of the natural ingridients that can be used is the banana plant (Musa paradisiaca). inter alia Amboina banana (Musa paradisiaca var. sapientum. This study aimed to determine the inhibition of Amboina banana stem on the growth of Candida albicans. This was an experimental laboratory study with a true experimental design and posttest only control group design with Kirby-bauer difusion method using filter paper. The parameter observed was fungal (Candida albicans) growth inhibition zona on pottatoe dextrose agar medium supplemented with saponin of Amboina banana stem. The growth proportion was analyzed by microsoft excell. The results showed that the average diameter of the inhibition zona of saponin was $12.5 \mathrm{~mm}$; ketokonazol $15.3 \mathrm{~mm}$; meanwhile aquades did not have the inhibition zona. Conclusion: Saponin in Amboina banana stem has an antifungal effect on the growth of Candida albicans.
\end{abstract}

Keywords: candida albicans, saponin, amboina banana stem

\begin{abstract}
Abstrak: Candida albicans yang hidup sebagai saprofit dapat ditemukan pada kulit, saluran genital, saluran napas bagian atas, dan saluran pencernaan termasuk rongga mulut. Perubahan Candida albicans dari saprofit menjadi patogen menyebabkan penyakit yang disebut kandidiasis atau kandidosis. Selain itu pada pemakai gigi tiruan, Candida albicans dapat menyebabkan denture stomatitis. Perawatan untuk infeksi ini dapat dilakukan dengan memberikan obat antijamur. Namun, pemberian obat antijamur dalam jangka waktu lama dapat menyebabkan resistensi. Hal ini memicu adanya kebutuhan untuk mencari pengobatan baru dengan aktivitas antifungi yang lebih baik, toksisitas yang lebih rendah, dan tidak resisten terhadap Candida albicans. Salah satu tanaman yang berpotensi sebagai tanaman obat yaitu tanaman pisang antara lain pisang Ambon (Musa paradisiaca var. sapientum). Penelitian ini bertujuan untuk mengetahui daya hambat senyawa saponin batang pisang Ambon terhadap pertumbuhan Candida albicans. Penelitian ini merupakan penelitian eksperimental laboratorik menggunakan rancangan eksperimental murni (true experimental design) dengan rancangan penelitian post test only control design dengan metode difusi lempeng agar Kirby-bauer menggunakan kertas saring. Parameter yang diamati ialah luas diameter zona hambat pertumbuhan jamur Candida albicans pada media agar yang telah diberi senyawa saponin batang pisang Ambon. Data dianalisis dengan menggunakan microsoft excell. Hasil penelitian menunjukkan total rerata luas diameter zona hambat senyawa saponin yang terbentuk sebesar 12,5 mm; ketokonazol 15,3 mm; sednagkan aquades tidak terdapat zona hambat. Simpulan: Senyawa saponin batang pisang Ambon dapat menghambat pertumbuhan Candida albicans.
\end{abstract}

Kata kunci: candida albicans, senyawa saponin, batang pisang ambon 
Dalam rongga mulut terdapat berbagai macam spesies mikroba yang salah satu di antaranya Candida albicans. Di dalam tubuh manusia, Candida albicans hidup sebagai saprofityang dapat ditemukan pada kulit, saluran genital, saluran napas bagian atas, dan saluran pencernaan termasuk rongga mulut. ${ }^{1,2}$ Pada orang sehat terdapat 30-60\% Candida albicans yang hidup normal di dalam mulutnya tanpa menimbulkan keluhan. Jamur ini dapat berubah menjadi patogen bila terdapat faktor resiko seperti menurunnya imunitas, gangguan endokrin, terapi antibiotik dalam jangka waktu lama, perokok, dan kemoterapi. ${ }^{3,4}$ Perubahan Candida albicans dari saprofit menjadi patogen menyebabkan penyakit yang disebut kandidiasis atau kandidosis.Selain itu pada pemakai gigi tiruan, Candida albicans dapat menyebabkan denture stomatitis. ${ }^{1}$

Pengobatan untuk infeksi Candida albicans dapat dilakukan dengan pemberian obat antijamur. Penggunaan obat antijamur dalam jangka waktu lama dapat menyebabkan resistensi. ${ }^{5} \mathrm{Hal}$ ini memicu adanya kebutuhan untuk mencari pengobatan baru dengan aktivitas antijamur yang lebih baik, toksisitas yang lebih rendah, dan tidak resisten terhadap Candida albicans.

Saat ini, banyak tanaman berkhasiat obat yang dipelajari secara ilmiah sebagai pengganti obat kimia. Salah satu tanaman yang berpotensi sebagai tanaman obat yaitu tanaman pisang. Produksi pisang di Indonesia menduduki tempat kelima dunia dengan besaran 3,6 juta ton atau 5\% dari produksi dunia. Buah pisang telah menjadi komoditas buah tropis yang sangat populer di dunia karena rasanya yang lezat, harga relatif murah, dan memiliki nilai gizi cukup tinggi antara lain sebagai sumber karbohidrat, vitamin, mineral, air, lemak, dan protein. ${ }^{6}$

Dari berbagi jenis varietas pisang yang ada, salah satu yang dapat dimanfaatkan sebagai tanaman obat yaitu pisang Ambon (Musa paradisiaca var. sapientum). Tanaman pisang ini terdiri dari akar, batang, pelepah, daun, bunga, dan buah. Beberapa penelitian menunjukkan bahwa bagian-bagian dari tanaman pisang Ambon memiliki banyak manfaat dalam dunia kedokteran, di antaranya sebagai antibakteri, antihipertensi, serta berperan dalam proses penyembuhan luka. ${ }^{7-10}$ Salah satu bagian yang dapat dimanfaatkan ialah bagian batang dari tanaman ini. Senyawa yang terkandung dalam batang pisang Ambon ini berupa saponin, tanin, dan flavonoid. Senyawa saponin berfungsi sebagai antibiotik, mempercepat pertumbuhan sel-sel baru, merangsang pembentukan fibroblast, menghambat pertumbuhan bakteri, dan juga bersifat antijamur. $^{8}$

Berdasarkan latar belakang di atas, maka peneliti tertarik untuk mengetahui daya hambat senyawa saponin batang pisang Ambon (Musa paradisiaca var. sapientum) terhadap pertumbuhan Candida albicans.

\section{BAHAN DAN METODE PENELITIAN}

Penelitian ini merupakan penelitian eksperimental laboratoris, menggunakan rancangan eksperimental murni (true experimental design) dengan rancangan penelitian post test only control design dengan metode difusi lempeng agar Kirbybauer menggunakan kertas saring. Parameter yang diamati ialah luas diameter zona hambat pertumbuhan jamur Candida albicans pada media agar yang telah diberi senyawa saponin batang pisang Ambon. Pembuatan ekstrak batang pisang Ambon dan isolasi senyawa saponin serta pengujian senyawa saponin terhadap Candida albicans dilakukan di laboratorium Kimia Fakultas M-IPA Universitas Sam Ratulangi pada bulan JuliAgustus 2015.

\section{HASIL PENELITIAN}

Hasil dari uji daya hambat senyawa saponin batang pisang Ambon pada jamur Candida albicans yang ditanam pada media Pottatoe Dextrose Agar dapat dilihat pada Gambar 1. Dalam satu cawan petri terdapat 
tiga perlakuan yang diberikan dan dilakukan tiga kali pengulangan. Seperti yang terlihat pada Gambar, kertas saring yang diberi senyawa saponin dan ketokonazol memiliki zona hambat yang berbeda, sedangkan kertas saring yang diberi aquades tidak memiliki zona hambat. Diameter zona hambat yang terbentuk dihitung dengan rumus luas diameter zona hambat (Tabel 1).

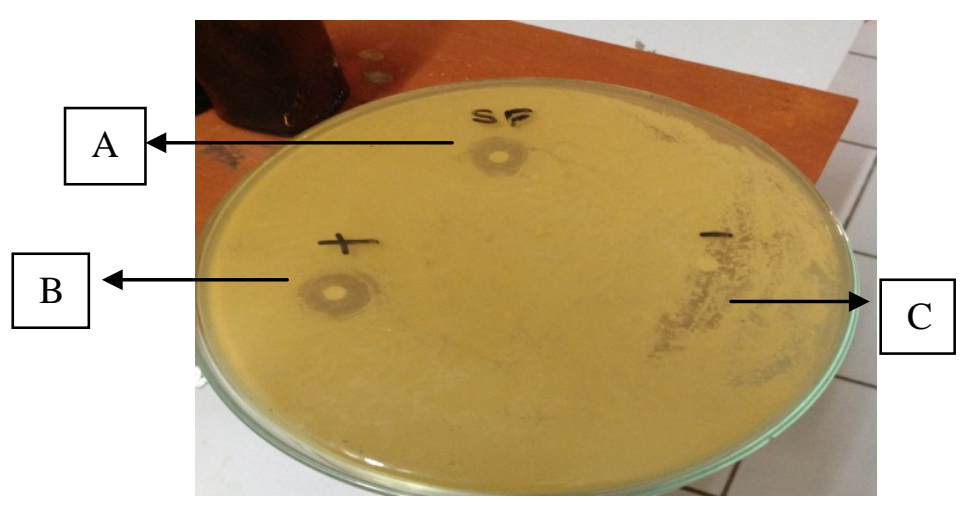

Gambar 1. Zona hambat yang terbentuk pada media Potattoe Dextrose Agar

Keterangan :

A : Kertas saring yang diberi senyawa saponin

$\mathrm{B}$ : Kertas saring yang diberi ketokonazol

$\mathrm{C}$ : Kertas saring yang diberi aquades

Dari Tabel 1 dilihat bahwa zona hambat yang terbentuk pada tiga kali perlakuan bervariasi. Total rerata zona hambat senyawa saponin terhadap Candida albicans sebesar 12,5 mm; total rerata zona hambat ketokonazol sebesar 15,3 mm; sedangkan pada aquades tidak terdapat zona hambat.

Tabel 1. Hasil perhitungan diameter zona hambat senyawa saponin batang pisang terhadap jamur Candida albicans

\begin{tabular}{cccc}
\hline \multicolumn{4}{c}{ Diameter zona hambat (mm) } \\
\hline Pengulangan & $\begin{array}{c}\text { Senyawa } \\
\text { saponin }\end{array}$ & $\begin{array}{c}\text { Ketokonazol } \\
(\text { kontrol +) }\end{array}$ & $\begin{array}{c}\text { Aquades } \\
\text { (kontrol -) }\end{array}$ \\
$\mathbf{1}$ & 11,5 & 13 & 0 \\
$\mathbf{2}$ & 13 & 18,5 & 0 \\
$\mathbf{3}$ & 13 & 14,5 & 0 \\
\hline
\end{tabular}

Rerata

12,5

15,3

0

\section{BAHASAN}

Berdasarkan hasil pengamatan dari tiga kali pengulangan, diameter zona hambat yang terbentuk bervariasi. Variasi diameter zona hambat yang dihasilkan dalam penelitian ini dapat disebabkan oleh perbedaan jumlah larutan isolat senyawa saponin dan jumlah larutan ketokonazol yang diserap oleh masing-masing kertas saring yang terdapat pada tiga cawan petri berbeda. Hal ini sesuai dengan pendapat Gillespie dimana kelemahan metode kertas saring yaitu tidak dapat diketahui secara pasti berapa besar jumlah larutan yang diserap oleh masing-masing kertas saring. ${ }^{11}$

Penyebab yang kedua ialah jumlah Candida albicans yang tersebar pada media pottatoe dextrose agar tidak tersebar merata di tiap area pada masing-masing cawan petri. Hal ini mungkin disebabkan karena pada saat pengolesan Candida albicans menggunakan dry glass sebagian jamur Candida albicans menempel pada area tertentu di media pottatoe dextrose agar yang menyebabkan penyebarannya tidak merata, sehingga diperoleh daya hambat yang berbeda. Hal ini juga sesuai dengan pendapat Gillespie dimana kelemahan metode kertas saring tergantung pada jamur yang diinokulasikan pada media. Jamur yang tidak tersebar merata pada media dapat mempengaruhi diameter zona hambat yang terbentuk. ${ }^{11}$

Zona hambat yang terbentuk pada kertas saring senyawa saponin disebabkan karena senyawa saponin dalam batang pisang Ambon (Musa paradisiaca var. sapientum) memiliki aktivitas antijamur yang dapat menghambat pertumbuhan jamur Candida albicans. Saponin mempunyai aktivitas sebagai antijamur dengan mekanisme kerjanya yaitu dengan cara merusak membran sel, sehingga menyebabkan kebocoran sel berupa keluarnya berbagai komponen penting dari dalam sel jamur yaitu protein, asam nukleat dan nukleotida yang akhirnya memacu kematian sel. ${ }^{12}$

Hasil penelitian tentang aktivitas 
antijamur senyawa saponin batang pisang Ambon (Musa paradisiaca var. sapientum), didukung oleh penelitian sebelumnya yang dilakukan oleh Herry dkk di Banjarmasin tahun 2013 yang menemukan bahwa batang pisang Mauli (Musa sp) memiliki aktivitas antijamur terhadap Candida albicans. Penelitian lain yang dilakukan oleh Hastari di Semarang tahun 2012, juga diperoleh hasil bahwa batang pisang Ambon (Musa paradisiaca var. sapientum) memiliki aktivitas sebagai antimikroba. Hal ini disebabkan karena pada batang pisang Mauli dan batang pisang Ambon memiliki senyawa yang sama, yaitu saponin dan berfungsi sebagai antijamur. ${ }^{8,13}$

Rerata zona hambat yang terbentuk pada kertas saring senyawa saponin lebih kecil jika dibandingkan dengan rerata zona hambat yang terbentuk pada kertas saring ketokonazol. Hasil tersebut menunjukkan bahwa ketokonazol memiliki daya hambat yang lebih besar jika dibandingkan dengan senyawa saponin. Hal ini mungkin disebabkan karena konsentrasi isolat senyawa saponin belum diketahui secara tepat minimum inhibitor concentration terhadap jamur Candida albicans sedangkan pada ketokonazol sudah diketahui minimum inhibitor concentration terhadap jamur Candida albicans, sehingga diameter zona hambat yang terbentuk pada ketokonazol lebih besar dibandingkan dengan diameter zona hambat yang terbentuk pada kertas saring. Rerata zona hambat yang terbentuk antara senyawa saponin dan ketokonazol sama-sama termasuk dalam kategori memiliki daya hambat yang kuat berdasarkan penggolongan Davis dan Stout. ${ }^{14}$

\section{SIMPULAN}

Senyawa saponin batang pisang Ambon (Musa paradisiaca var. sapientum) dapat menghambat pertumbuhan jamur Candida albicans.

\section{SARAN}

Perlu dilakukan penelitian lebih lanjut mengenai daya hambat senyawa saponin terhadap pertumbuhan Candida albicans dengan menggunakan minimum inhibitor concentration.

\section{DAFTAR PUSTAKA}

1. Komariah, Sjam R. Kolonisasi Candida dalam rongga mulut. Majalah kedokteran FKUI 28(1). Jakarta: Departemen parasitologi FK UI, 2012; p. 39-47.

2. Babiak R, Rosen S, Blozis GG, Schmitt JA. An epidemiological study on Candida albicans in the oral cavity. Ohio: The Ohio Journal of science 1978;78(2):88-91.

3. Maulani C, Jubile E. Kiat merawat gigi anak. Jakarta: Elex Media Komputindo, 2005; p. 83.

4. Scully C, El kabir M, Samaranayake LP. Candida and oral candidosis: a review. Crit Rev in Oral Biol Med 1994;5(2):125-57.

5. Revankar SG, Olga PD, Kirkpatrick WR, Mcatee RK, Fothergill AW, Rinaldi MG, et al. Clinical evaluation and microbiology of oropharyngeal infection due to fluconazole resistant candida in human immunodeficiency virusinfected patients. Clin Infect Dis 1998;26:960-3.

6. Wibowo RD. Sifat fisis dan mekanis akibat perubahan temperatur pada komposit polyester serat batang pisang yang di treatment menggunakan $\mathrm{KmnO}_{4}$ [Naskah publikasi]. Surakarta: Universitas Muhammadiyh; 2014.

7. Nur J, Dwyana Z, Abdullah A. Bioaktivitas getah pelepah pisang ambon musa paradisiaca var sapientum terhadap pertumbuhan bakteri staphylococcus aureus, pseudomonas aeuroginosa dan eschericia coli [Skripsi]. [cited 2015 mei]. Makassar; Fakultas MIPA UNHAS. p. 8-9. Available from: http://repistory.unhas.ac.id.

8. Hastari R. Uji Aktivitas antibakteri ekstrak pelepah dan batang tanaman pisang ambon [Karya tulis ilmiah]. Semarang: Fakultas Kedokteran Universitas Diponegoro; 2012. p. 29.

9. Tryastuti D. Pengaruh konsumsi pisang ambon (Musa paradisiaca S) terhadap tekanan darah lansia penderita hipertensi sedang di panti sosial 
Tresna Werdhasabai Nanaluihsicincin [Skripsi]. Padang: Fakultas Kedokteran Universitas Andalas; 2012. p. 5.

10. Pongsipulung GR, Yamlean PVY, Banne Y. Formulasi dan pengujian salep ekstrak bonggol pisang ambon (Musa paradisiaca var. sapientum (L.)) terhadap luka terbuka pada kulit tikus putih jantan galur wistar (Rattus norvegicus). Pharmacon 2012; 1(2): p. 12. Available from: http://ejournal.unsrat.ac.id/index.php/ pharmacon/article/view/462. Diakses Mei, 2015.
11. Pelczar MJ, Chan ES. Dasar-dasar mikrobiologi (2nd ed). Jakarta: Universitas Indonesia, 1988; p. 20.

12. Ganiswarna. Farmakologi dan terapi. Jakarta: EGC, 1995; p. 800-10.

13. Septianoor MH, Carrabelly AN, Apriasari ML. Uji efektivitas antifungi ekstrak metanol batang pisang Mauli (Musa sp) terhadap Candida albicans. Jurnal PDGI 2013; 62(1):2-4.

14. Davis WW, Stout TR. Disc plate method of microbiological antibiotic essay. Appl Microbiol 1971;22(4):659-65. 